\title{
Pengaruh Latihan Berjalan Di Atas Balok Kayu Terhadap Keseimbangan Dinamis
}

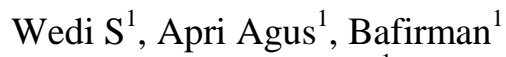 \\ Universitas Riau $^{1}$ \\ Emile: wedi.s@lecturer.unri.ac.id
}

\begin{abstract}
Abstrak
Tujuan dari penelitian ini adalah untuk mengetahui pengaruh dari latihan berjalan di atas balok kayu terhadap keseimbangan dinamis. Jenis penelitian ini adalah eksperimen semu (Quasi experiment) dengan populasi penelitian berjumlah 30 orang yang merupakan siswa dari Sekolah Dasar Negeri 02 Sarilamak Kabupaten 50 Kota. Data tes diambil dengan tes keseimbangan menggunakan papan keseimbangan (balance board).Teknik analisis data yang digunakan untuk menguji hipotesis adalah dengan analisis uji t pada taraf signifikan 5\%.Hasil analisis data menunjukkan bahwalatihan berjalan di atas balok kayu memberi pengaruh terhadap peningkatan keseimbangan dinamis siswa Sekolah Dasar Negeri 02 Sarilamak. Pengaruh ini sebesar 9,13, yaitu dari skor rata-rata 18,47 pada pre test menjadi 27,60 pada post test.
\end{abstract}

Kata Kunci : berjalan di atas balok kayu, keseimbangan dinamis

\section{The Effect of Walking on Wooden Beams Exercise to Increase Dynamic Balance}

\begin{abstract}
The purpose of this study was to determine the effect ofwalking on wood beams exercise on dynamic balance of elementary school students 02 Sarilamak.This research is a quasi-experiment with 30 population and sampling. Data test taken with the balance board test. The data analysis technique used to test the hypothesis is the analysis of the t test at significance level of 5\%.The results showing that :walking on wood beams exercise give an effect to the dynamic balance of elementary school students 02 Sarilamak. This exercise was take effect to dynamic balance of 9.13, is from an average score of 18.47 at pre-test to post-test becomes 27.60.
\end{abstract}

Keywords :walking on wood beams exercise, dynamic balance 


\section{PENDAHULUAN}

Untuk mendapatkan keseimbangan yang baik, terdapat banyak faktor yang mempengaruhinya, diantaranya upaya pemberian latihan keseimbangan tidak atau kurang terprogram. Selain itu ada faktor lain yang juga mempengaruhi keseimbangan yaitu adanya pengaruh pusat gravitasi, bidang tumpuan, bidang gravitasi, sensori organ, dan kekuatan otot (Souder \& Hill 1963:108). Keseimbangan menurut Pajnan \& Sarabon (2010: 131) adalah "kemampuan dasar gerakan manusia untuk menjaga posisi tubuh selama anti-gravitasi kegiatan serta postur tubuh yang tepat untuk pelaksanaan gerakan sekunder lainnya".

Definisi keseimbangan menurut Browne (2001) adalah "kemampuan untuk mempertahankan pusat gravitasi pada bidang tumpu terutama ketika saat posisi tegak". Keseimbangan juga bisa diartikan sebagai suatu proses dimana tubuh berusaha mempertahankan posisinya saat melakukan berbagai kegiatan. Keseimbangan melibatkan berbagai gerakan di setiap segmen tubuh dengan didukung oleh bidang tumpuan, dengan bidang tumpu akan membuat manusia mampu untuk beraktivitas secara efektif dan efisien. Selain itu, keseimbangan menurut Kreighbaum \& Barthels (1981:243) terbagi atas dua kelompok yaitu:"keseimbangan statis merupakan kemampuan tubuh untuk menjaga keseimbangan pada posisi diam ataupun istirahat, dan keseimbangan dinamis adalah kemampuan tubuh untuk mempertahankan keseimbangan ketika bergerak dengan kecepatan dan arah yang konstan".

Jadi dapat disimpulkan bahwa keseimbangan adalah kemampuan untuk mempertahankan tubuh dalam posisi seimbang baik dalam keadaan statik atau dinamik, serta menggunakan aktivitas otot yang minimal sehingga akan membuat manusia mampu untuk beraktivitas secara efektif dan efisien. Melihat kenyataan bahwa demikian pentingnya keseimbangan di dalam berolahraga, maka peneliti mencoba memberikan bentuk latihan yang dapat meningkatkan keseimbangan.

Rentang waktu yang dibutuhkan untuk melihat hasil eksperiment (pengaruh dari suatu latihan) menurut Pate dan Bowers : "6 - 8 minggu latihan untuk memberikan efek yang cukup berarti bagi atlet". Latihan akan diberikan kepada anak-anak usia sekolah dasar dengan rentang usia 9 tahun pada putri dan usia 11 tahun pada putra, karena menurut Warsono \& Sajoto dalam Gusril (2008) menyatakan :"Pada masa anak adalah masa perkembangan yang paling baik dan perkembangan kondisi fisiknya cepat, pada anak perempuan peningkatan tercepat dimulai usia 9-10 tahun sedangkan pada anak laki-laki pada usia 11-12 tahun. Sehingga pada usia ini baik untuk melatih faktor-faktor pembentuk kondisi fisik seperti kekuatan, daya ledak, daya tahan, kecepatan, kelincahan, kelentukan, koordinasi, dan keseimbangan".Jadi seperti yang telah dijelaskan di atas, usia anak-anak merupakan kelompok usia yang berada dalam proses perkembangan yang baik untuk melatih 
kondisi fisiknya, sehingga diharapkan latihan yang akan diberikan dapat memberikan efek yang cukup baik.

Setelah penulis melakukan observasi di Sekolah Dasar Negeri 02 Sarilamak, dan meminta 20 orang untuk berjalan di atas balok kayu dengan tinggi $50 \mathrm{~cm}$ dan panjang $10 \mathrm{~m}$, ternyata banyak dari siswa yang terjatuh. Berdasarkan hal tersebut dapat dikatakan bahwa keseimbangan dinamis siswa Sekolah Dasar Negeri 02 Sarilamak masih kurang baik. Hal ini mungkin disebabkan kurangnya pemberian kesempatan belajar dan tidak terlaksana dengan baik. Sedangkan untuk mendapatkan keseimbangan dinamis yang baik ada banyak faktor yang mempengaruhinya, diantaranya pemberian latihan keseimbangan yang tidak terlaksana dan terprogram, sehingga peneliti menjadikan Sekolah Dasar Negeri 02 Sarilamak sebagai tempat penelitian untuk mengembangkan bentuk latihan kemampuan dasar kondisi fisik salah satunya adalah keseimbangan dinamis.

Untuk mendapatkan keseimbangan yang baik, terdapat banyak faktor yang mempengaruhinya, diantaranya upaya pemberian latihan keseimbangan tidak atau kurang terprogram. Selain itu ada faktor lain yang juga mempengaruhi keseimbangan yaitu adanya pengaruh pusat gravitasi, bidang tumpuan, bidang gravitasi, sensori organ, dan kekuatan otot (Souder \& Hill 1963:108).

Agar kegiatan peningkatan keseimbangan anak dapat terlaksana dengan baik, maka anak dituntut memiliki perhatian yang baik
pula.Selain itu ada faktor-faktor lain yang juga dapat mempengaruhi kegiatan latihan seperti disiplin, kerjasama, kecepatan bereaksi, jujur, berkonsentrasi sesuai kemampuan anak. Dengan harapan bisa meningkatkan kemampuan keseimbangan dinamis melalui latihan berjalan di atas balok kayu pada siswa Sekolah Dasar Negeri 02 Sarilamak.

\section{METODOLOGI PENELITIAN}

Metode yang digunakan dalam penelitian ini adalah eksperimen semu (Quasi experiment)yang dilakukan selama enam minggu atau 18 kali pertemuan. Bentuk rancangan penelitian pre-testdan post-test(the one group pre-tes post-tes design),artinya sebelum diberi perlakuan sampel melakukan test awal dengantes keseimbangan. Setelah itu sampel diberikan perlakuan dengan melakukan latian berjalan di atas balok kaayu selama 18 kali pertemuan selama 6 minggu dengan volume latihan 3 kali dalam seminggu. Setelah diberikan perlakuan baru diadakan test akhir (post-test) untuk melihat apa ada pengaruh dari latihan tersebut.

Populasi dalam penelitian ini adalah semua siswa Sekolah Dasar Negeri 02 Sarilamak yang berusia 9 tahun untuk putri dan 11 tahun untuk putra yaitu sebanyak 30 orang.Teknik pengambilan sampel dalam penelitian ini diambil secara total sampling, dimana seluruh populasi yang digunakan dalam penelitian ini dijadikan sampel yaitu siswa putra sebanyak 19 orang dan siswa putri sebanyak 11 orang dengan jumlah sampel 30 orang. Untuk terlaksananya proses latihan dengan baik maka diperlukan penyusunan jadwal latihan dan 
program latihan. Penentuan atau pelaksanaan latihannya dilakukan latihan sebanyak 18 kali pertemuan dengan frekuensi 3 kali dalam seminggu dan lama waktu latihan lebih kurang adalah 60-70 menit

Tabel 1: Jadwal Latihan Keseimbangan Per Minggu

\begin{tabular}{cccc}
\hline No & Hari & Waktu & Lama \\
\hline 1 & Senin & $16.00-17.00$ & $60-70$ Menit \\
\hline 2 & Rabu & $16.00-17.00$ & $60-70$ Menit \\
\hline 3 & Jumat & $16.00-17.00$ & $60-70$ Menit \\
\hline
\end{tabular}

\section{HASIL DAN PEMBAHASAN}

Keseimbangan dapat ditingkatkan dengan latihan. Latihan adalah suatu proses berlatih yang sistematis yang dilakukan berulangulang, dan yang kian hari jumlah beban latihannya kian bertambah. Selain itu latihan menurut Sukadiyanto dan Muluk (2011:25) adalah "suatu proses pengakumulasian dari berbagai komponen latihan yaitu durasi, jarak, frekuensi, repetisi, intesitas, volume, dan interval latihan".

Dari beberapa pendapat di atas dapat diketahui bahwa latihan adalah proses implementasi dari perencanaan materi latihan yang telah direncanakan sebelumnya dalam bentuk aktivitas-aktivitas fisik yang dilakukan secara berulang-ulang dengan pengaturan beban mengikuti prinsip-prinsip latihan secara teratur dan terencana sehingga dapat memperbaiki kemampuan ataupun keterampilan.

Salah satu bentuk latihan keseimbangan adalah latihan berjalan di atas balok kayu. Latihan berkembang menjadi tiga set dan 15-20 pengulangan". berjalan di atas balok keseimbangan merupakan salah satu bentuk latihan yang digunakan oleh atlet senam untuk meningkatkan keseimbangannya, sehingga peneliti mencoba memakai cara latihan ini untuk meningkatkan keseimbangan. Latihan dilakukan di atas balok keseimbangan sepanjang 10 meter dengan tinggi $50 \mathrm{~cm}$ dari permukaan lantai dan lebar balok $12 \mathrm{~cm}$ (Jhonson, 1986:248). Dalam latihan berjalan di atas balok ini sampel dapat melakukan latihan dimulai dari latihan yang paling sederhana yaitu latihan berjalan maju. Kemudian materi latihan dapat ditingkatkan dengan berjalan ke sampingdan latihan berjalan mundur.

Latihan stabilisasi atau keseimbangan menggunakan sistem set seperti dikutip dari http://www.coachr.org/core_stabilisati on_traning menjelaskan: "Latihan tersebut dilakukan tiga kali per minggu, untuk memaksimalkan latihan atlet mulai dengan satu-dua set dan 15 repetisi kemudian

Fase latihan adalah suatu susunan atau urutan dari suatu program latihan yang akan 
diberikan. Adapun urutan tentang latihan yaitu sebagai berikut: pemanasan (warming out), latihan inti, pendinginan (cooling down). Gerakan-gerakan dalam latihan ini harus mulai dilakukan dengan latihan yang ringan agar siswa dapat beradaptasi dengan baik. Kemudian dilakukan berbagai pengembangan dari berbagai materi latihan tersebut seperti berjalan maju, berjalan ke samping dan berjalan mundur. (Apriagus dan Bafirman, 2008). Berdasarkan hasil analisis uji hipotesis diperoleh harga thit $(4,49)>$ ttabel $(1,70)$ pada taraf signifikansi $\alpha=0,05$ pada jumlah sampel berjumlah 30. Jadi, dapat disimpulkan bahwa Ho ditolak dan Ha diterima.Dengan demikian latihan berjalan di atas balok kayu memberikan pengaruh yang signifikan terhadapterhadap keseimbangan dinamis siswa Sekolah Dasar Negeri 02 Sarilamak. Akhirnya didasarkan pada pembuktikan uji statistik, disimpulkan bahwa latihan berjalan di atas balok kayu memberikan pengaruh terhadap kemampuan keseimbangan dinamis. Sehingga program latihan ini dapat terus dikembangkan dan dilaksanakan agar tujuan dalam latihan dapat tercapai yaitu meningkatkan kemampuan keseimbangan dinamis

\section{SIMPULAN}

Berdasarkan analisis data dan pembahasaan, maka dapat disimpulkan bahwa: Latihan berjalan di atas balok kayu memberikan pengaruh yang berarti terhadap kemampuan keseimbangan dinamis siswa Sekolah Dasar 02 Sarilamak, artinya latihan meniti balok kayu dapat meningkatkan keseimbangan dinamis siswa Sekolah Dasar Negeri 02 Sarilamak.

\section{DAFTAR PUSTAKA}

Apriagus.2012. Olahraga Kebugaran Jasmani sebagai Suatu Pengantar. Padang: Sukabina Press

Apriagus \& Bafirman. 2008. Pembentukan Kondisi Fisik. Padang: FIK UNP

Browne, J., \& O'Hare, N, 2001. A Review of the Different Methods for Assessing Standing Balance.Ireland. Dublin Institute of Technology

Gusril. 2008. Model Pengembangan Motorik Pada Siswa Sekolah Dasar. Padang: UNP PRESS

http://www.coachr.org/core_stabilisation_train ing

Jhonson, B.L, Nelson, J.K. 1986. Practical Measurements For Evaliation In Physical Education. New York: Macmillan Publishing Company

Kreighbaum, E \& Barthels, K.M. 1981.Biomechanics A Qualitative approach for studying human movement. USA: Burgess Publishing company

Pajnan, A., \& Sarabon, N. 2010.Review of Methods for the Evaluation of Human Body Balance.Sport Science Review, vol. XIX, No. 5-6

Pate, R.R, McClenaghan, B, dan Rotella, R. 1993.Dasar-Dasar Ilmiah

Kepelatihan. Semarang, IKIP Semarang Press

Souder, M.A \& Hill, P.J. 1963.Basic Movement Foundations Of Physical 
Education. New York: The Ronald Press Company

Suharsimi Arikunto, 1989. Prosedur Penelitian Suatu Pendekatan Praktik. Jakarta: Rineka Cipta

Sukadiyanto dan Muluk, Dangsina.

2011.Pengantar Teori dan
Metodologi Melatih Fisik. Bandung: Lubuk Agung

Syafruddin. 2012. Ilmu Kepelatihan Olahraga. Padang: UNP PRESS

Traetta, J \& Jhon. 1985. Dasar-Dasar Senam. Bandung: Angkasa Bandung 